\title{
Presenting the Conceptual Model of Citizen Sports
}

\author{
Meisam Allahmoradi ${ }^{1}$, Seyed mohammad hossein Razavi ${ }^{2}$, Morteza Doosti pashakolaee ${ }^{3}$ \\ 1. Meisam Allahmoradi, (Ph.D Student) Ayatollah Amoli Branch, Islamic Azad University, Amol, Iran. \\ 2. Seyed mohammad hossein Razavi, (Ph.D) Mazandaran University, Babolsar, Iran \\ 3. Morteza Doosti pashakolaee, (Ph.D Mazandaran University, Babolsar, Iran
}

\section{ARTICLE INFO}

Received September 2018

Accepted February 2019

\section{KEYWORDS:}

Citizen Sports

Grounded Theory

National Interest

Sport Development

Urban Management

CITE:

Allahmoradi, Razavi, Doosti pashakolaee, Presenting the Conceptual Model of Citizen Sports, Research in sport management \& motor behavior, 2020: 9(18):17-35

\section{ABSTRACT}

Today, because of living in the machines age and the resulted less mobility and activity of citizens, the diverse and accessible sports for the citizens has become more important. This research which was carried out by qualitative methodology with fundamental-exploratory nature and using the grounded theory is aimed at designing a conceptual model for citizen sports in Tehran metropolitan area. The purposeful-snowball sampling method was used in the research. Accordingly, in order to collect the data, 25 experts of citizen sports were interviewed, and the Strauss and Corbin paradigm analysis was used to develop the final model. Given the results, motivational and health factors were identified as causal conditions, the hardware and software context was identified as the dominant field, the behavioral, structural and environmental level factors were identified as the intervening conditions. Also, promotional, legal, financial, educational, interactive and developmental measures were identified as strategies, and securing national interests, economic consequences, sport development, healthsanitary and socio-cultural outcomes were identified as the strategies implementation results. Given these findings, one can expect that by identifying the citizen sports conditions and concentration on strategic actions, the functional and operational facilities for its development and growth would be provided in Tehran metropolitan area. 


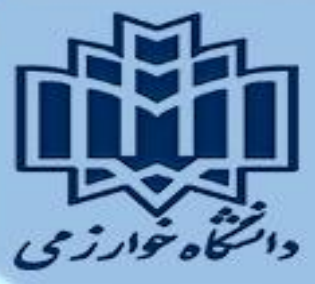



\section{ارائه مدل مفهومى ورزش شهروندى در تهران}

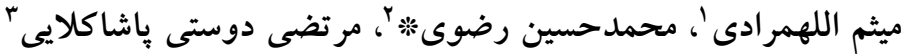

ا. دانشجوى دكترى مديريت ورزشى، واحد آيتالله آملى، دانشخاه آزاد اسلامى، آمل، ايران

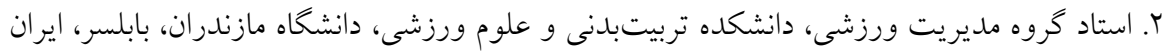



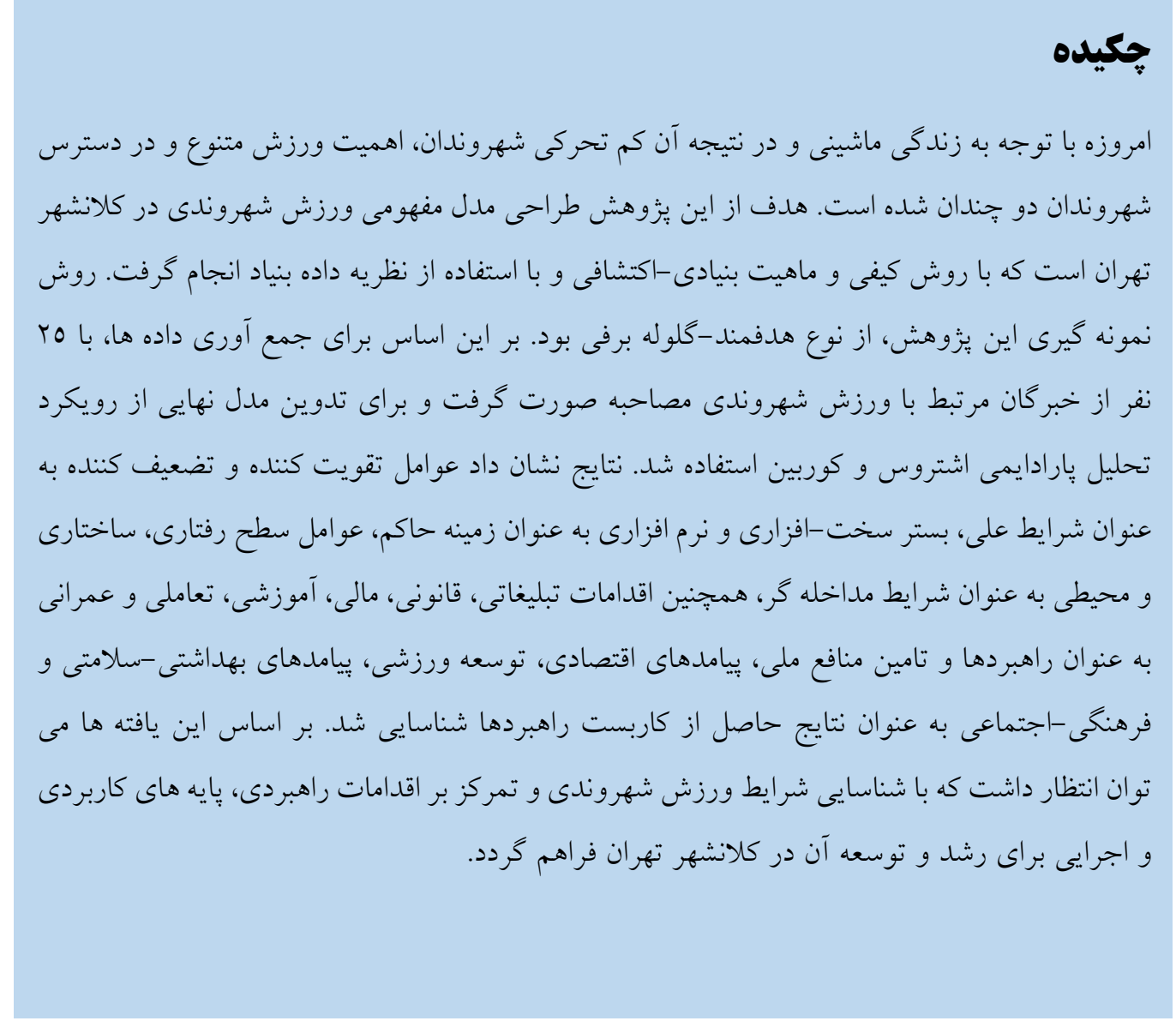

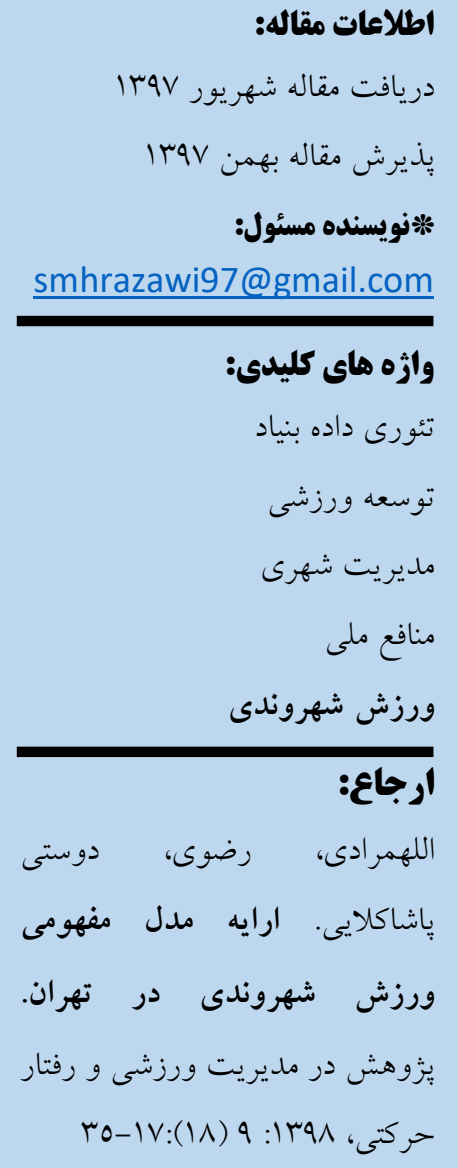

https://jrsm.khu.ac.ir/ 


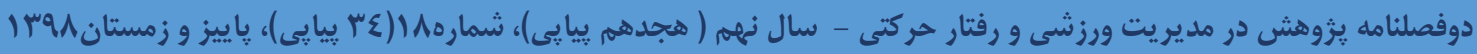

\section{مقدمه}

در طى نيمقرن كذشته شرايط اجتماعى، سياسى و اقتصادى جهان دستخوش تغيير و تحولات زيادى بوده است. با توجه به مشغله زياد شهروندان در كلانشهرها، زندگى ماشينى و توسعه فنّاورى و رفاه، سبك زندگى افراد باكم تحركى

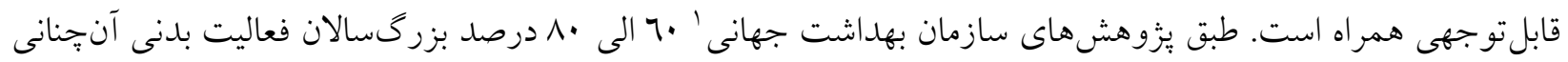
ندارند، كه مى تواند بهعنوان يكى از علل مر گومير شناخته شود. جر اكه بىتحركى موجب افزايش بيمارىهايى جهون ديابت، فشارخون بالا، يوكى استخوان، مشكلات قلبى-عروقى، مشكلات روحى -روانى و غيره مىشود. همجنين طبق كزارشها، در كلانشهرها بيشترين علت مرگومير براثر ايست قلبى است. بر اساس بررسىهاى صورت گرفته، انجام فعاليتهاى مناسب ورزشى احتمال ابتلا به مشكلات جسمانى مطرحشده (كه به بيمارىهاى شهرى معروفاند) را تا حد يكسوم

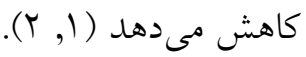

در حال حاضر در كشور ايران ورزش در اذهان مردم به فعاليتهايى رقابتى جهت دستيابى به عناوين قهرمانى معنا مىشود و اين نخرش بلهوسيله رسانهاى گروهى، مديران ورزشى و سياستمداران موردحمايت قرار مى گيرد. همجنين مزاياى مادى، شهرتى و سفرهاى خارجى و هيجانات كاذب ناشى از بردوباخت، ورزش قهرمانى را بهعنوان يك اصل، محور توجه مديران ورزشى مملكت قرار داده و سايه آن را بر سر ورزش همخانى و شهروندى مستولى كردانيده است (ب, ع). بر اين اساس، شهروندان علاقهمند به ورزش ممكن است باكم توجهى مديران به فراهم آورى اماكن عمومى فعاليت ورزشى، صرفاً باهدف تماشا و لذت به سمت ورزش بيايند و در معرض آسيبهاى ذكرشده زندگى ماشينى قرار كيرند. نكته مهمى كه در اينجا بايد به آن اشاره كرد تفاوت بين ورزش شهروندى و ورزش همخانى است. وازهها و عبارات مختلفى براى مفهوم ورزش همگانى به كار مىرود. رايجترين اصطلاح بينالمللى براى ورزش همخانى عبارت "ورزش براى همه"rاست. ورزش همخانى يعنى ورزشى كه همه افراد در همهجا و هرزمانى كه توانستند، در هر رشتهاى كه تمايل به آن دارند، جهه بهصورت فردى و جّه گروهى به آن بيردازند تا نشاط، شادابى، سلامت جسم و روح خويش را ارتقا دهند (0). "درحالىكه مفهوم ورزش شهروندى فراتر از اينهاست و به درى اجتماعى افراد از زندكى شهرى، امكانات و موقعيتهاى موجود در آن، يتانسيل وعلاقمندى منطقهاى، امكان انجام دادن اكثر رشتهاى ورزشى مثل ورزش هاى رزمى، ايروبيك، بدنسازى، بازىهاى تويى از قبيل واليبال، بدميتتون، فوتبال گلكوجك، بسكتبال، تنيس روى ميز،

1 WHO

2 sport for all

https://jrsm.khu.ac.ir/ 


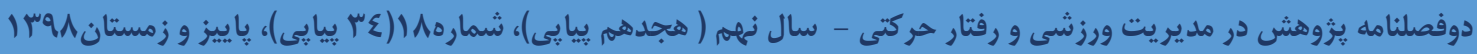

هندبال و... و با داشتن جندين كيلومتر ساحلهاى زيباى كنار درياها و درياجهها و توجه به ورزشهاى ساحلى است. بنابراين ورزش محلات در بسيارى از رشتهاى تويى و بلدون توبٍ، سازماندهى و برگزارى خودجوش تمرينات و حتى مسابقات در روزهاى تعطيل از ضرورتهاى تغيير نخرش به اين مفهوم وسيع است" (7).

ازأنجايى كه يزوهش درزمينهذ ورزش شهروندى محدود بوده، بنابراين با تمركز بر موضوعات و مفاهيم همراستا و نزديك به ورزش شهروندى ازجمله شهروندى، مديريت شهرى و ورزش، ضمن تعريف هركدام از آنها، به تحقيقاتى كه داراى هميوشانى مفهومى و موضوعى با بحث مىباشند، برداخته خواهد شد. ابتدا به سراغ مفهوم شهروندى مىرويم. ممكن است شهروندى را بهعنوان وضعيتى تعريف كنيم كه به يك شخص اجازه مىدهد (اهمراه با ديخر شهروندان در تصميمات جمعى كه زندگى اجتماعى را تنظيم مى كند شركت كند). با بيشرفت جوامع شهرى امروزى، مغهوم شهروندى نيز موردتوجه بيشترى قراركرفته است. شهروندى را منزلتى اجتماعى در نخرش به جامعهمانى مىداند كه بستر بهرهبردارى از حقوق و قدرت را مهيا مى كند (N،V). كاركرد شهروندى، اداره جامعه بر اساس حفظ حقوق ديخران و تعهد شهروندان به وظايفى است كه در جامعه بر عهدهدارند تا با مشاركت در نهادهايى كه حقوقشان را بايدار مىكند، از آن حفاظت و

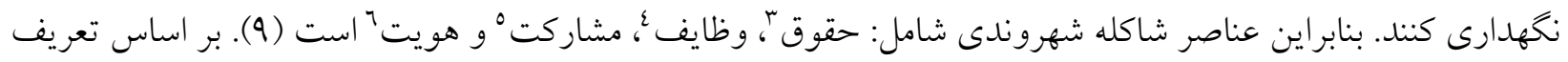
مفهوم شهروندى و با درى عناصر آن، اهميت اداره و مديريت شهر و امورات شهروندان بر كسى يوشيده نخواهد بود. بنابراين نقش مديريت شهرى در فراهم كردن بستر فعاليتهاى شهروندى موردتوجه ويزه قرار مى گيرد.

نقش مديريت شهرى در رابطه با وظايف و تكاليف متعدد شهرى از اهميت بسزايى برخورداراست. شامل فعاليتهاى توسعه بخش، خدمات، امور فرهنگى، تفريحى و ورزشى در توسعه شهرها، مراقبت از سلامت و ارائه تسهيلات براى اوقات فراغت شهروندان. ارائه تسهيلات ورزشى در توسعه شهرها يكى از نيازها و حقوق شهروندان است. ازاينرو شهردارىها به لحاظ قانونى از اهميت بسزايى برخوردارند و همجنين از ديدكاه افراد ارزش و جايگاه رفيعى دارند. در قوانين، شهردارىها وظايف مهمى نسبت به توسعه ورزش و تسهيلات رفاهى دارند. باينكه كامهايى در راستاى ارائه تسهيلات ورزشى براى شهروندان را برداشتهشده است، اما باز در آغاز راه بوده و نيازمند بيمودن مسيرى طولانى است ( •(1). بر اين اساس، هدف مديريت شهرى ارتقاى كيفيت زندگى در سطح شهر است كه با عنايت به مطالب مطرحشده و

\footnotetext{
3 Rights

4 Duties

5 Participation

${ }^{6}$ Identity
}

https://jrsm.khu.ac.ir/ 


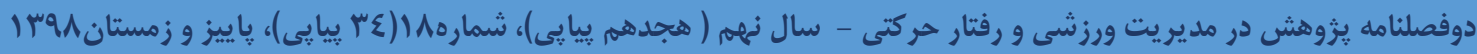

ضرورت توجه مديريت شهرى به ارتقاى سلامتى و وظايف آن در قبال شهروندان، نقش ورزش در بيشخيرى از بيمارى و رشد سلامت يررنخت مى گردد. يس ابتدا لازم است به تعريف مفهوم ورزش بيردازيم.

آزّانس فدرال كانادا كه كار نظارت بر توسعه ورزشى را در اين كشور به عهده دارد "ورزش" را بهصورت فعاليتى رقابتى بين دو يا تعداد بيشترى از شركت كنند گان تعريف مى كند كه انجام دادنش نيازمند مهارتهاى خاص عصبى -عضلانى و قلبى - عروقى است، اين نهاد به شكل واضحى، قواعد و قوانينى را در اين مورد تدوين كرده است، فرصتهايى را براى كسترش رقابت فراهم كرده و بر توسعه اجر ايى آن در سرتاسر جهان نظارت دارد (11). اكنون با نخاهى به ادبيات يزوهش در دو بخش خارجى و داخلى، تحقيقات بيرامون موضوع را بررسى خواهيمكرد.

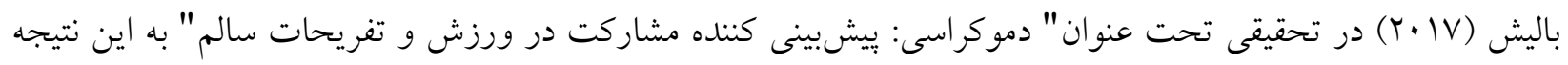
رسيد كه در كشورهاى كه ميزان مردمسالارى در آنها بالاست، ميزان مشاركت در ورزش و فعاليتهاى تفريحى نيز بالاست. همجنين وى به اين نتيجه رسيد كه در كشورهايى كه مقدار دموكراسى كمى بالاتر از حد متوسط است، ميزان مشاركت زنان در فعاليتهاى ورزشى بالاست(1). هاويت و اسكاكر (17 (Y) در تحقيقى تحت عنوان"بيامدهاى كيفى مشاركت در ورزش و تفريحات فعال بدنى بر اساس مدل كيفيت خدمات" به اين نتيجه رسيدند كه مهمترين بيامد مشاركت رضايتمندى است كه از طريق وفادارى به فعاليتهاى ورزشى و تفريحى به دست مى آيد( (I). سوارى و همكاران(ع وبا) در تحقيقى تحت عنوان" توصيف وضعيت ورزش همگانى استان خوزستان و تدوين راهبردهاى توسعه آن" به اين نتيجه رسيدند كه وضعيت ورزش همخانى استان خوزستان بر اساس ماتريس SWOT در

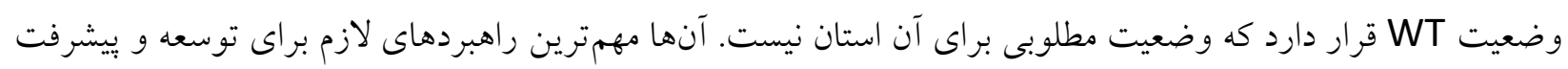
ورزش همگانى در استان خوزستان را تدوين برنامه راهبردى، توسعه و ترويج فرهنگ ورزش از طريق رسانها و تغيير


اثربخشى برنامههاى تفريحات ورزشى(ورزش همخانى) شهروندان" به اين نتيجه رسيد كه براى بررسى ميزان اثربخشى برنامهاى تفريحى ورزشى شهروندان، تدوين اهداف در اولويت اول است و تا هدف ها روشن و قابل دستيابى و قابل سنجش

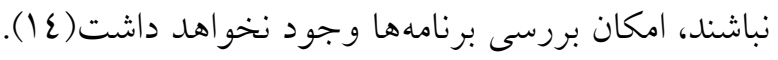

اكنون يّ از بيان مقدمه و درى مفاهيم كلى، و پِ از مرورى بر تحقيقات لازم است به نكته اشاره كرد كه بر اساس بررسى هاى صورت گرفته توسط محقق در منابع داخلى و خارجى، تعريف دقيق و روشنى از ورزش شهروندى وجود نداشت، جراكه برخى اوقات اين مفهوم را با ورزش همخانى يكى دانسته و برخى اوقات با توجه به بسترهاى موجود در آن، ورزش قهرمانى مدنظر بوده است. نكته قابل توجهتر اينكه در اكثر منابع ادبيات ييشينه، توجهى به مفهوم شهروندى و 


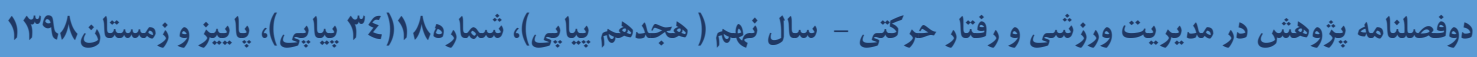

ابعاد و معانى آن نخشته و خلأ يك تعريف جامعومانع در اين مفهوم بشدت احساس مى گردد. بهعبارتديخر با توجه به جديد و گُنگ بودن ورزش شهروندى در منابع علمى، سازمانها و ادارات و اركانهاى مختلفى بدون كشف و بسط دانش نظرى آن، سرمايه هاى عظيم مادى و مالى و معنوى را در اين بخش هزينه كرده و در صورت ادامه اين روند با توجه به خلأ نظرى موجود، ماحصل آن هدر رفت بودجه و سرمايههاى شهرى و حتى ملى خواهد بود. ازاينرو محقق ضمن شناخت خلأ موجود، به دنبال كشف يك مدل مفهومى براى ورزش شهروندى است تا با درى معانى و مفاهيم آن، بر اساس نتايج تحقيق، به رشد و بسط دانش نظرى در اين حوزه دستيافت.

با عنايت به مباحث مطرحشده در فوق، اهميت ورزش شهروندى و رابطه آن با مباحث مرتبط باكيفيت زندكى بيشازييش روشن مىشود. بنابراين نياز به شناخت ويز گیىاى آن در كشور- با توجه به اقتضائات بومى - محلى كشور - بيشازييش احساس مىشود. البته بايد متذكر شد كه تلاشهايى در كلانشهر تهران از سوى سازمان ورزش شهردارى براى تبيين اين يديده انجامشده است. تحقيق حاضر مىتواند ضمن ارائه راهكارهايى جهت مشاركت مردم در ورزش شهروندى، بستر نظرى افزايش فضاهاى ورزشى براى همه افراد جامعه با كمك شهردارى و ساير اركانهاى دولتى ديخر را فراهم آورد. همجنين با ارائه دستاوردها، مىتوان خلأ ورزش شهروندى در بين آحاد جامعه را در اولويت دستور كار برنامهريزان شهرى قرار داده تا جايخاهو نقش شهردارىها در توسعه و ترويج ورزش با تكيهبر مطالعات و تحقيقات موجود تبيين كردد. از همين رو در اين تحقيق تلاش مىشود كه ويزگىهاى بومى-محلى كشور مدنظر قرار كيرد و مدلى جامع از ورزش شهروندى براى كلانشهر تهران ارائه شود كه مبناى كنشها و اقدامات آينده در اين زمينه باشد.

\section{روش رشناسى يُوهش}

اين تحقيق با ماهيت اكتشافى و باهدف بسط دانش و شناخت موجود در مورد ورزش شهروندى صورت كرفت. بر مبناى جستجوى داده، ماهيت اين تحقيق كيفى است كه از راهبرد و نظريه داده بنياد استفاده شد. استفاده از اين راهبرد به محقق كمك مى كند بين حجم بالاى دادهها، به شكلى نظاممند وجوه اشتراى را استخراج كند و بر طبق آن نظريهيردازى كند. رويكرد راهبرد داده بنياد، استقرايى است. تبيين يك يديده از طريق مشخص كردن مفاهيم، مقولات و قضاياى آن بديده و و بعداز آن طبقهبندى روابط مقولات داخل بستر و فرآيند آن، هدف اين راهبرد است. توليد و خلق مفاهيم، مقولات و قضايا نيز فرآيندى جرخه ایى-تكرارى دارد (10). 


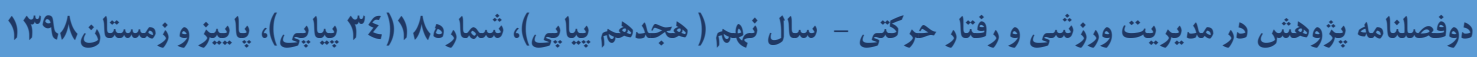

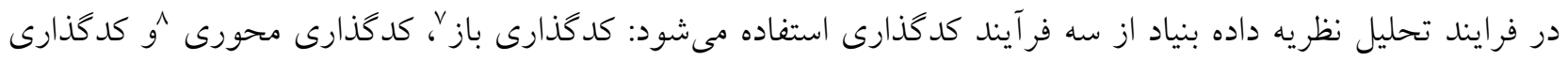
انتخابى" (7 (1). به همين منظور براى افزايش ميزان كفايت مقولهها، تلاش شد كه جمعآورى و تحليل دادهها بهصورت همزمان صورت بخيرد. در طى تحليل، جندين بار متن مصاحبهها براى اصلاح مدل يا ايجاد مقولات جديد و رسيدن به مدلى نو، موردبازنخرى قرار كرفت. در اين يزوهش بهمنظور ارائه يك مدل نظاممند از يافتهاى حاصل از كدگذارى، از مدل بارادايمى •' اشتراوس و كوربين استفاده شد. در اين مدل، يكى از طبقات تعيينشده بهعنوان مقوله محورى انتخاب و ساير طبقات موجود بر اساس نظامى از روابط كه با اين طبقه دارند، قرار مى گيرند (IV).

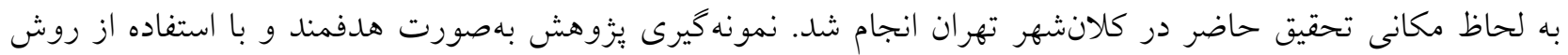
نمونه گيرى كلوله برفى صورت كرفت. نمونه كيرى تا رسيدن به اشباع نظرى ادامه يافت. منظور از اشباع نظرى اين است كه يزوهشكر در مصاحبههاى جديد ديخر به دادهاى نو (يا در فرآيند كد گذارى، به كدى نو) دست نيابد (17). در اين تحقيق از اعضاى هياتعلمى دانشخاهها و از افراد داراى يست و تجربيات مديريتى مرتبط با موضوع و از كارشناسان و مربيان ورزش شهروندى در مصاحبهها استفاده شود. بنابراين با تعداد ب نفر از نخبخان مرتبط با ورزش شهروندى در شهر تهران در ارتباط با يديده موردبررسى يزوهش مصاحبه شد كه از مصاحبههاى رودررو و عميق و با طرح يرسشهاى باز و نيمهساختارمند بهره كرفته شد. فر آيند انجام مصاحبهها و جمع آورى دادهها از دىماه 90 آغاز و تا مهرماه 97 به طول انجاميد. در جدول زير تعداد اعضاى نمونه به تفكيك هر دسته بيانشده است.

جدول ا. تعداد اعضاى نمونه مشاركت كننده در يزوهش

\begin{tabular}{|c|c|c|}
\hline تعداد شر كت كندكًان & كروه & 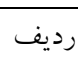 \\
\hline$r$ & اعضاى هيات علمى & 1 \\
\hline ir & معاو نان و مديران ارشد شهردارى تهر ان (ورزشى، عمر انى) & r \\
\hline v & كارشناسان ورزش شهردارى & $r$ \\
\hline r & مربيان ورزش شهردارى & $\varepsilon$ \\
\hline ro & جمع & 0 \\
\hline
\end{tabular}

\footnotetext{
${ }^{7}$ Open coding

${ }^{8}$ Axial coding

${ }^{9}$ Selective coding

${ }^{10}$ Paradigm model
}

https://jrsm.khu.ac.ir/ 


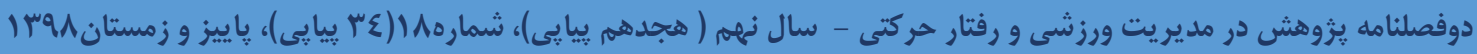

جهت مميزى تحقيق كيفى حاضر (معادل روايى و بايايى تحقيق كمى) فعاليتهاى زير صورت گرفت: تطبيق توسط اعضا": جهار نفر از مديران مرتبط با ورزش شهروندى گزارش نهايى مرحله نخست فرآيند تحليل و مقولههاى بهدستآمده را بازبينى كردند. كثرت گرايى با: كثرت گرايى در اين بُزوهش شامل تكثر مكانى و كثرت مشاركت كنندگان است. تكثر مكانى به اين معنى كه مصاحبه با مديران مرتبط با ورزش شهروندى انجام شد. تكثر مشاركت كنندكان نيز به اين معنى است كه مصاحبه با افراد سطوح مختلف سازمانى از قبيل هياتعلمى، معاونان و مديران سازمان ورزش شهروندى، مديران شهرسازى شهردارى تهران، مربيان و ...صورت كرفت. جهت تائيد اتكايذيرى (يايايى) يزوهش از روشهاى زير بهره كرفته شد: استفاده از نرمافزارهاى تحليل كيفى: يكى از راههاى رسيدن به پِيايى در يزوهش كيفى استفاده از نرمافزارهاى تحليل دادهاى كيفى است كه بدين منظور يزٔوهشخر از آخرين نسخه نرمافزار مكس كيودىاى با استفاده شد. كدگذارى مجدد توسط محقق ديخر: · 1 درصد از كليه كدگذارىهاى انجامشده در اختيار يزوهشخر ديخر قرار گرفت كه ميزان توافق كدگذارى در حد قابل قبولى بود (ضريب اسكات برابر با |N/•)، كه نشانى ديخر از قابلاتكا بودن مدل يزّوهش است. درنهايت كدگذارى و مدل نهايى در اختيار سه نفر از اعضاى هياتعلمى قرار كرفت و آنها نظرات خود را اعمال كرده و درنهايت مدل نهايى تحقيق را تائيد كردند.

\section{يافتهها}

جهت تدوين يك الكوى منطقى كه با توصيف نظرى همراه است، محقق از رهيافت نظاممند اشتراوس و كوربين استفاده كرد. اين رهيافت جهت تحليل دادهها و رسيدن به مدل، سه مرحله كدكذارى باز، محورى و انتخابى را يِشنهاد مى كند (17) (17). مراحل كدگذارى بهصورت زير ادامه يافت:

\section{كدتذارى باز}

كدهاى اوليه: در ابتدا يس از انجام كدكذارى دادهها، إع9 كد اوليه از عباراتمعنايى استخراج گرديد كه يس از بررسى و بايش مجدد كدهاى اوليه، درنهايت NVI كد اوليه مستخرج گرديد.

\footnotetext{
${ }^{11}$ Member checking

12 Triangulation

${ }^{13}$ Maxqda 12 pro
}

https://jrsm.khu.ac.ir/ 


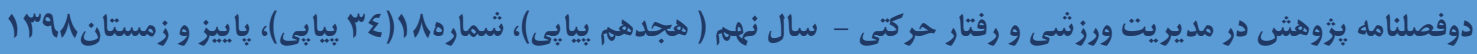

زير مفهوم: برخى از كدهاى اوليه، كه همبستخى معنايى داشتند، در قالب · Tا زير مفهوم ساماندهى شدند. مفهوم: پِ از درى كدهاى اوليه و عباراتمعنايى آنها، با توجه به معنايى كه از طريق آنها منتقل مىشد، برخى از زير مفهومها كه خود داراى وزن معنايى بيشترى نسبت به ساير زير مفهومها بودند، بهتنهايى همراه با كد اوليه و عباراتمعنايى شأن در يك طبقه بالاتر در قالب يك مفهوم، و برخى ديخر كه باهم تشكيل مفهوم جديدى را مىدادند، در تجميع بهعنوان مفهومى نو قرار داده شدند و درنهايت همخى كدهاى اوليه و زير مفهومها در قالب 07 مفهوم خاص به دست آمدند. مقولات: با بررسى مجدد و بايش معنايى مفاهيم طى مراحل كدگذارىهاى مجدد و از نو، 19 مقوله كه شالودهى طراحى مدل است، ايجاد كرديد. نمونهاى از كدگذارىها به شرح جدول (Y) ارائهشده است.

جدول ז. نمونهاى از كدگذارى اوليه تا تشكيل زير مفاهيم، همراه با عباراتمعنايى و مصاحبهشوندكان

\begin{tabular}{|c|c|c|c|}
\hline 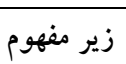 & 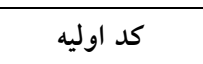 & عبارتمعنايى & نشانگر (منبع) \\
\hline \multirow{4}{*}{ سلامت } & & ورزش به جهت اينكه سلامت شهروندان رو ارتقا مىدهد & هيات علمى 1 \\
\hline & ارتقا سلامتى & 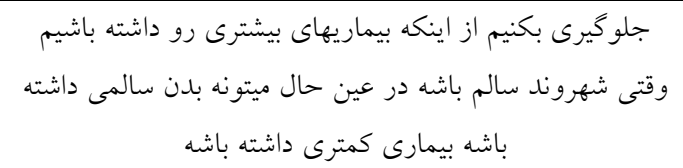 & كارشناس r \\
\hline & افزايش طول عمر & ميتونه افزايش طول عمر شهروندان رو هم داشته باشه. & 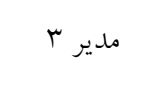 \\
\hline & زودوسي جامعه ازيرى & 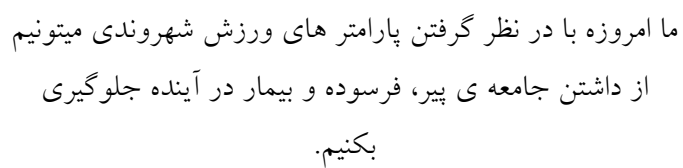 & كارشناس 1 \\
\hline
\end{tabular}



عبارتست از سلسله رويه هايى كه يس از كدگذارى باز انجام مى شود تا با برقرارى بيوند بين مقولات، اطلاعات را به شيوهاى جديد با هم مرتبط سازد (IV). بدين منظور مقولات در قالب الكوى اشتراوس و كوربين در 7 طبقهى اصلى قرار

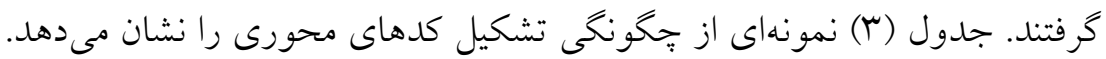




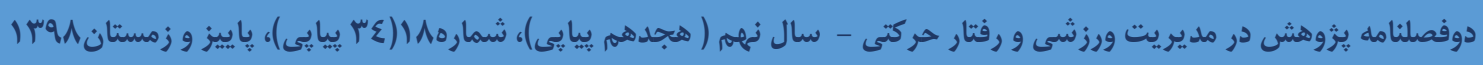

جدول r. نمونهاى از كدكذارى باز و محورى در طراحى مدل مفهومى ورزششهروندى

\begin{tabular}{|c|c|c|c|}
\hline 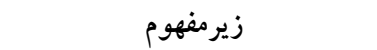 & 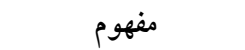 & 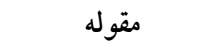 &  \\
\hline مشاركت سياسى & \multirow{6}{*}{ منافع سياسى } & \multirow{9}{*}{ تامين منافع ملى } & \multirow{16}{*}{ 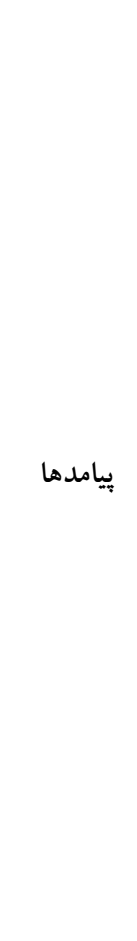 } \\
\hline كمى به ثبات و بايدارى كشور & & & \\
\hline مشاركت بين المللى شهرها & & & \\
\hline ارتقا باور هاى ملى & & & \\
\hline تقويت هويت ملى & & & \\
\hline موفقيت نيابتى & & & \\
\hline 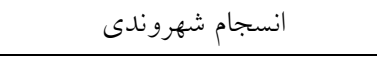 & \multirow{3}{*}{ منافع امنيتى } & & \\
\hline دفاع از وطن & & & \\
\hline بهبود وضعيت امنيتى مناطق شهرى & & & \\
\hline جلوگيرى از اشغال اراضى & \multirow{4}{*}{ كسترش رفاه عمومى } & \multirow{7}{*}{ ييامدهاى اقتصادى } & \\
\hline كاهش هز ينه هاى درمانى & & & \\
\hline صرفه جويى اقتصادى & & & \\
\hline كمك به اقتصاد خانواده & & & \\
\hline تو سعه ى تاسيسات و خدمات & \multirow{3}{*}{ توسعه اقتصاد شهرى } & & \\
\hline افزايش كار و اشتغال & & & \\
\hline افزايش توليد ناخالص ملى & & & \\
\hline
\end{tabular}

براساس رويههاى مطرحشده در قسمت روششناسى و همينطور، نمونه كدگذارى ارايه شده در بالا، مدل نهايى به شرح زير است: در اين مدل براى تبيين ورزش شهروندى شش طبقه تعيين شد. بر اساس طرح اشتراوس و كوربين، ابتدا مقوله محورى را مشخص مى كنيم و سبس آنرا در طبقهمحورى قرار ميدهيم كه به اين منظور بـ آز گردآورى دادهها و تحليل آنها در فرآيند كدگذارى، مقوله ورزش شهروندى به عنوان مقولهمحورى تعيين شد. طبقه بعدى شرايط على است، كه به حوادث يا وقايعى دلالت مى كند كه منجر به وقوع يا گسترش يديده اى مى شود. از بين مقولات موجود، عوامل انخيز اننده و تضعيف كننده به عنوان شرايطعلى به حساب آمد. طبقه بعدى بسترحاكم است كه سلسله شرايط خاصى است كه در آن راهبردها، براى اداره، كنترل و ياسخ صورت مى گيرد. اين شرايط و بستر را دو مقوله بستر سخت افزارى و بستر نرم افزارى فراهم مى آورند. طبقه بعدى شرايط مداخله گر است كه شرايط كلى و وسيعى هستند و به منزلهى زمينهى ساختارى وسيع تر مربوط به يديده مىباشند. بنابراين در سه سطح، مقولات سطح اجرايى، سطح ساختارى و سطح محيطى شرايطمداخله گر در ورزشهروندى شناسايى شد. 


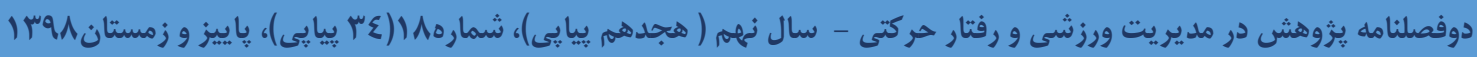

طبقه بعدى راهبردهاست كه به كنشها و تعاملات نيز شناخته مى شود كه با استفاده از روشها و راهبردهايى جامهى عمل مى يوشاند و از شر ايط مداخله كر و بسترها و زمينه تاثير مى يذيرد و خود بر بيامدها نيز تاثير كذار است(IV). راهبردهاى تبليغاتى، قانونى، مالى، آموزشى، تعاملى و عمرانى در اين طبقه قرار دادهشد. طبقه آخر نيز نتايج و بيامدهاست كه در اثر راهبردها به وجود مى آيند. مقولات تامين منافع ملى، بيامدهاى اقتصادى، توسعهورزشى، بيامدهاى فرهنگى -اجتماعى و بهاشتى سلامتى در اين طبقه قرار دادهد. مدل نهايى تحقيق در شكل (1) نشان داده شده است.

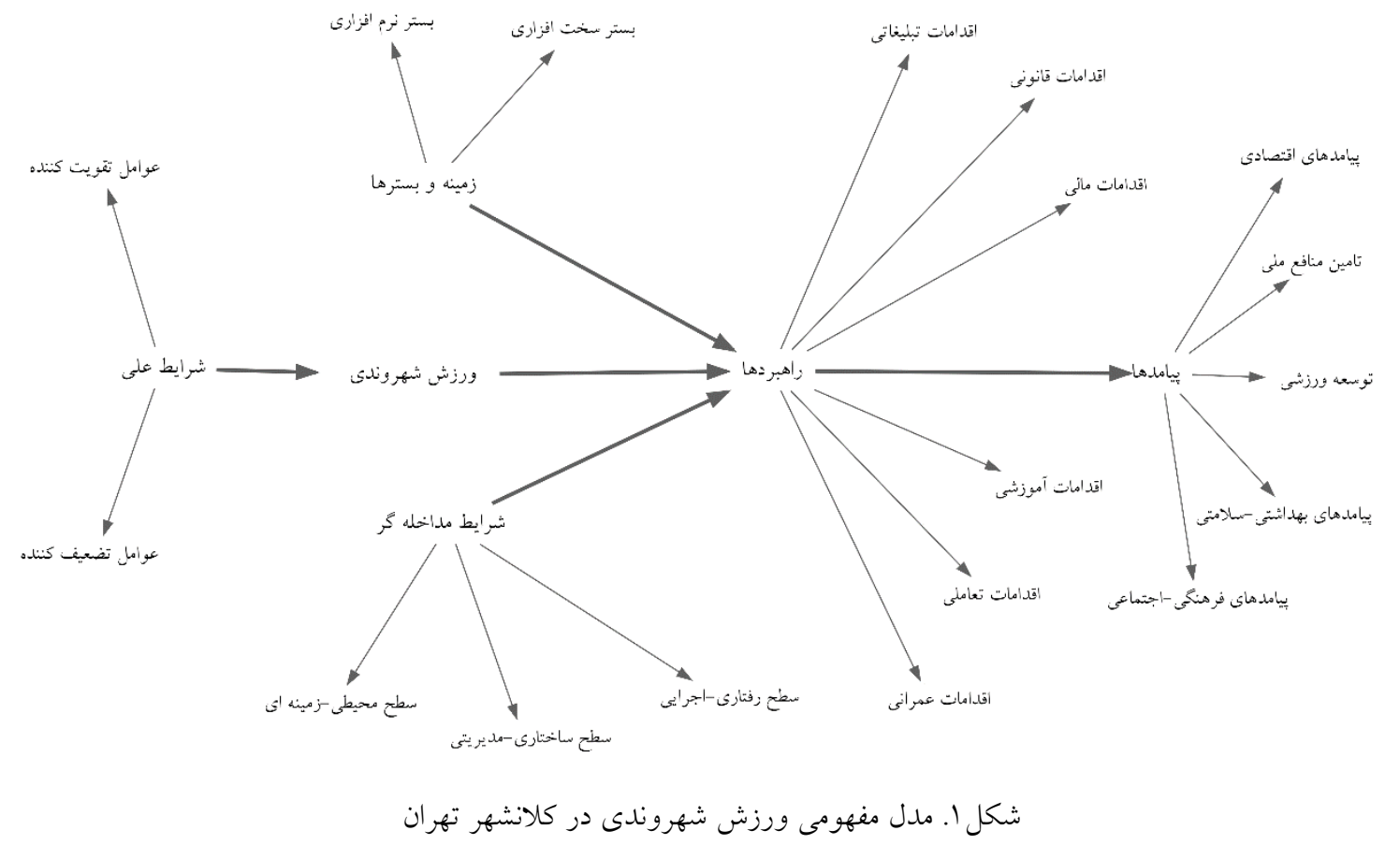

با توجه به يافته هاى حاصل از يزوهش، و بر اساس مدل مفهومى تحقيق، در طبقه محورى، ورزش شهروندى به عنوان مقولهمحورى قرار دادهشد. از داده هاى حاصل يزوهش و نتايج كدگذارى باز و محورى، زير مقولات آن شناسايى شدهو تعيين گرديد (كه مجموعا داراى اله فراوانى در تكرار كدها بود-براى ورزش شهروندى، ورزش-شهروندى و مفاهيم آن ها). ورزش شهروندى شامل دو زيرمقوله ورزش و شهروندى است. طبق مصاحبههاى صورت گرفته و نتايج كدگذارى، زيرمقوله ورزش داراى مفاهيم: ورزش آموزشى و تربيتى با فراوانى سץ كد، ورزش براى همه با فراوانى الح كد، ورزش قهرمانى با فراوانى זو كد و ورزش حرفه اى با فراوانى · ا كد است. نكته قابل توجه اينكه در مصاحبه هاى صورت گرفته و بر اساس فراوانى كدها، در مقوله ورزش شهروندى توجه مشاركت كنند گان به ورزش قهرمانى بيش از ساير بخشهاى ورزش بود كه مىتواند مورد توجه مسئولان و برنامه ريزان قرارگيرد. از طرفى براى زيرمقوله شهروندى، مفاهيم: وظايف شهروندى rا كد، حقوق شهروندى سج كد، مشاركت شهروندان با فراوانى rr كد و هويت ايرانى -اسلامى با فراوانى سع 


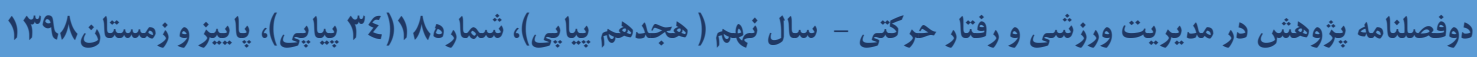

كد تعيين كرديد. همجنين بايد توجه كرد كه مفهوم هويت ايرانى -اسلامى در زيرمقوله شهروندى با بيشترين فراوانى، نشان دهنده توجه مصاحبهشوندكان به اين مفهوم مى باشد كه نشان از اهميت آن دارد. با عنايت به يافتهاى حاصل از تحقيق پس از فرايند كد گذارى باز و محورى و تعيين ابعاد و مولفههاى ورزش شهروندى، اكنون مرحله نهايى يزوهش، يعنى كدگذارى انتخابى را بيان مى كنيم.

\section{كدگذارى انتخابى}

عبارتست از ارتباط دادن ساير مقولات با مقوله محورى، بركردن خلا، با مقولاتى كه نياز به توسعه دارند و فرآيند اعتبار بخشى به نظريه (IV). به همين منظور يس از كد گذارى محورى، قضاياى زير از الكوى يارادايمى استخراج گرديد:

قضايا

ا-شر ايط على ايجاد مقوله ورزش شهروندى عوامل تقويت كننده و عو امل تضعيف كننده ورزش شهروندان مىباشند. ז-زمينهها (بستر سخت افزارى و بستر نرم افزارى)، بسترى خاص را براى فعاليتهاى ورزش شهروندى ايجاد مى كنند.

ץ-شرايط مداخله كر (عوامل محيطى، ساختارى، رفتارى)، شرايط عامى را براى ورزش شهروندى فراهم مى آورند. ع-راهبردها (تبليغاتى، قانونى، مالى، آموزشى، تعاملى، عمرانى) از جمله راهبردهاى مورد نظر براى دستيابى به مفاهيم ورزش شهروندى مى باشند. 0-دستيابى به مفاهيم ورزش شهروندى در كلانشهر تهران، ييامدهاى تامين منافع ملى، توسعه اقتصادى، توسعه ورزشى، ييامدهاى بهلاشتى -سلامتى و فرهنخى -اجتماعى را به دنبال خواهدداشت.

\section{بحث و نتيجه كيرى}

در اين يزوهش، براى رسيدن به هدف تحقيق و باسخ به سولات يزٔوهش، با اجراى راهبرد داده بنياد، مدل مفهومى زير استخراج شد و به اين گونه قابل تفسير و روايت است:

\section{مقولهمحورى}

مقولهمحورى اين بزوهش ورزش شهروندى بود كه به معنى خلق فرصتها و محيط مطلوب ورزشى از طريق همكارى تمام سازمانهاى دركير (دولتى و غير دولتى) براى اينكه هرفردى بدون توجه به جنسيت، سن، توانايى، موقعيت اجتماعى - اقتصادى و نزاد بتواند در فعاليتهاى جسمانى و ورزش شركت نمايد؛ است. تمام اين سازمانها به مسئوليت ملى براى اطمينان از اينكه هر شهروند حق مساوى براى مشاركت در فعاليتهاى ورزشى و جسمانى دارند؛ اشاره مى كنند و دولت

و سازمانهاى غيردولتى نقش مهمى در دستيابى به مشاركت در ورزش و فعاليتهاى جسمانى ايفا مىنمايند (1).

https://jrsm.khu.ac.ir/ 


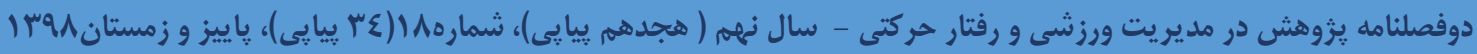

طبق يافتهاى حاصل از يزوهش، مولفههاى ورزش شهروندى شامل دو مولفه ورزش و شهروندى مى باشد. بر اساس مصاحبه هاى صورت گرفته با نمونههاى تحقيق، ابعاد مولفه ورزش بر اساس مدل سلسله مراتبى ورزش مول و همكاران (19)، به جهار مفهوم ورزش حرفهاى، ورزش قهرمانى، ورزش براى همه و ورزش آموزشى و تربيتى تقسيم شد. از طرفى براى مولفه شهروندى، جهار مفهوم وظايف، حقوق، مشاركت و هويت شهروندى همسو با بزوهش دلانتى (199V) شناسايى شد. وى بيان مى دارد شهروندى دال بر عضويت جامعه سياسى است و به لحاظ داخلى توسط حقوق، وظايف، مشاركت و هويت تعريف مى گردد. و به لحاظ سنتى فرع بر مليت بودهاست كه حدود سرزمينى شهروندى را معين مى كند (Y.). با عنايت به مقولات و مفاهيم حاصل از يزوهش، به برخى تعاريف خبر گان از ورزش شهروندى مى بردازيم: "خوب حالا دوستان ميكن ورزش همخانى همون ورزش شهرونديه ولى من مخالفم شديدا مخالفم با اين موضوع "(دانشجوى دكترى Y). "خوب اينكه از دو كلمه تشكيل شده (اورزش) و ((شهروند)) خوب كاملا تعريفش معلومه؛ يعنى اينكه ما فعاليتهاى بدنى كه انجام بشه براى سلامتى شهروندان باشه و اون فعاليتها، فعاليتهايى باشه كه خيلى راحت و خيلى آسان در اختيار شهروندان قرار گرفته بشه و هدف اون فعاليت هم نشاط، سلامتى و تندرستى شهروند باشه"(كارشناس (). "خوب؛ واقعيت امر اين هستش كه تعريف واحدى كه يذيرفته شده باشه از طرف محققان در رابطه با ورزش شهروندى توى ذهن من نيست و من فكر مى كنم كه يك وفاق هم وجود نداره راجع به ورزش شهروندى. اما اكه بخوايم تجزيه كنيم اين مفهمومى كه شما كفتيد؛ ما با دو تا كلمه سر و كار داريم يكى ورزش و ديخرى شهروندى كه هر كدوم تعاريف خاص خودشون رو دارن؛ در رابطه با ورزش، ما يك تعريفى كه مىتونيم ارائه بديم يك بازى سازمان يافته هستش كه حداقل دو تا طرف دارد و بر اساس يكى انخيزه درونى و بيرونى افراد به رقابت ميبردازند؛ اما در رابطه با شهروندى يكسرى تعاريف وجود داره؛ ما مىتونيم بخيم كه شهروند كسى هستش كه مقيم يك فضاى جغر افيايى هستش و در اون فضاى جغرافيايى بر اساس آداب، رسوم، هنجارها و قواعد و قوانينى كه وجود داره عمل مىكنه. خب ما اكه بخوايم تعريف كنيم مىتونيم بخيم كه ورزش شهروندى شكلى از ورزش هستش با تعاريف خاص خودش كه مقيد به يك جارجوب مكانى و جغر افيايه! پيس اون قواعد جغرافيايى، هنجارها و شيوههاى عملى كه وجود داره، يك نهادى رو ايجاد ميكنه به اسم ورزش شهروندى و بر اساس اقتضائات جغرافيايى كه وجود داره يك سرى فعاليتها انجام ميشه تحت عنوان ورزش شهروندى؛ حالا ميتونه اون تعاريف جهار كانه ورزش رو هم شامل بشه در ورزش شهروندى"(هيات 


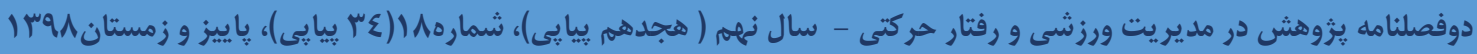

شرايط على

در اين يزوهش يس از تحليل دادهها، علل تاثير كذار بر مقولهمحورى به دو دسته عوامل تقويت كننده و عوامل تضعيف كننده تقسيم شدند. بنابراين بر اساس نظر مشاركتكنندكان در بزووهش، مجموعه عوامل تقويت كننده و تضعيفكننده موجب احساس نياز و حركت سياستخاران، شهروندان، سازمانها و اركانهاى دخيل در ورزش شهر تهران به سمت مقولهى نو و جديد ورزش شهروندى شدهاست. در اين تحقيق عوامل تقويتكننده شامل مفاهيم: فاصله بين ورزش همخانى و قهرمانى، ورود شهردارى تهران به مقوله ورزش، جديد بودن مفهوم ورزش شهروندى، مشاركت سازمان هاى مختلف در ورزش و نياز شهروندان به ورزش است. از طرفى عوامل تضعيفكننده يا بازدارنده اى كه در محيط شهرى و ورزشى تهران وجود داشت و به عنوان مفاهيم بازدارنده از مشاركت در ورزش محسوب مىشدند شامل مفاهيم: خطرات آينده جامعه، سبك زندگى غير فعال شهروندان، خالى بودن جايگاه ورزش در منشور حقوق شهروندى كشور، نبود مدل ورزشى مناسب براى شهروندان، مديريت ضعيف اماكن ورزشى سطح شهر تهران و در نهايت عدم بهرهورى برنامههاى ورزشى اجرايى براى شهروندان بود.

\section{بستر ها و زمينه}

بستر يا زمينه محل وقوع حوادث و اتفاقات مرتبط با يديده است كه در اين يزوهش دو دسته بستر سختافزارى و بستر نرمافزارى شناسايى شد. مفاهيم بستر سختافزارى شامل شهر ورزشى، محيط و بستر كلانشهرى تهران و امكانات و سرانه ورزشى موجود مىباشد. از طرفى بستر نرمافزارى شامل مفاهيم: حوزه تفريحات، فعاليتهاى آموزشى، ورزش همه اقشار و سنين و زمينه فعاليتهاى رقابتى بود كه بر راهبردها و استراتزىهاى برنامه ريزىشده ورزش شهروندى تاثير كذار

هستند.

در راستاى ارتقاى جايگاه شهردارى ها در مديريت شهرى، آنان بايد مسيرى طولانى طى كنند و نقش مهمى در توسعه شهرى و ورزش شهروندان ايفا كنند. ير واضح است كه هر جا جامعه نيازمند نيروى انسانى يويا، متعهد و سالم است و دسترسى به تسهيلات ورزشى بهترين شيوه رسيدن به يك اجتماع سالم و داثتن يك شهر سالم است، زيرا يك شهر سالم درگرو يكى شهر توسعهيافته با شهردارى كارآمد است. از اين رو، شهردارى به عنوان يكى عامل ضرورى ورزش شهروندى، نيازمند طرحهاى منجسم و برنامهريزىهاى كارآمد جهت دستيابى به يك شهر توسعهيافته است( (Y). همانطور كه در كشور هلند برنامههايى براى افزايش زيرساخت هاى ورزشى و همكارى ميانبخشى در شهردارىها، نقش كليدى در ارتقاى فعاليتهاى ورزشى و فيزيكى دارد (YT). 


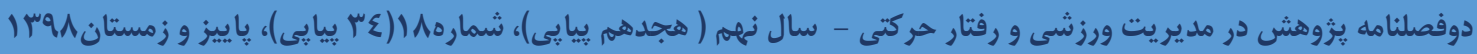

عوامل مداخله

بر اساس تئورى سهشاخگى ميرزايى اهرنجانى كه بيان مى دارد بِديده را مى توان در سه دسته عوامل رفتارى، ساختارى و زمينهاى تجزيه و تحليل كرد (T)، عوامل مداخله گ در ورزش شهروندى كه بر راهبردهاى آن تاثير گذار هستند شامل سطح اجر ايى -رفتارى، مديريتى -ساختارى و در نهايت محيطى-زمينهاى است. بنابر نتايج اين تحقيق سطح رفتارى شامل: محدوديت بانوان در انجام ورزش شهروندى، عدم فرهنگسازى مناسب و بازخورد رفتارى شهروندان به مديران شهرى است. در سطح ساختارى دو دسته عوامل مداخله گر مرتبط با مديريت شهرى و مديريت ورزشى شناسايى گرديد. در مديريت شهرى زيرمفاهيم: نبود مديريت يكيارجهه شهرى در كلانشهر تهران و وظايف مديريت شهرى در قبال شهروندان شناسايى شد. در مورد مفهوم مديريت ورزشى نيز زيرمفاهيم: مشكلات مديريتى ورزش كشور و مشكلات ساختارى اماكن ورزشى تعيين گرديد. در مورد سطح سوم، يعنى سطح زمينه نيز محيط سياسى، فرهنگى، اقتصادى و محيط زيست شهر تهران به عنوان مفاهيم اين مقوله از منظر مصاحبهشوند گان قرار دادهشد.

\section{اقدامات و راهبر دها}

بر اساس نتايج تحقيق حاضر اقدامات راهبردى زير براى ورزش شهروندى در كلانشهر تهران تبيين شد: اقدامات تبليغاتى شامل مفاهيم: توسعه نظام تبليغى، اطلاعرسانى و آكاهسازى شهروندان و ترغيب سران كشور به منافع اجتماعى ورزش مى باشد. اقدامات قانونى شامل مفاهيمى از قبيل: سياستخذارى مجلس در ورزش شهروندى و سياستذارى دولت در ورزش شهروندى تعيين گرديد. همجنين اقدامات مالى با مفاهيم درآمدزايى ورزش شهروندى، تخصيص بودجه مناسب به ورزش شهروندى و اختصاص يارانه ورزشى به گروههاى خاص در نظر گرفتهشد. از نظر مشاركت كنند كان در يزوهش اقدامات آموزشى شامل مفاهيم پِنجخانه: الكوسازى، فرهنگسازى، آموزش شهروندى و

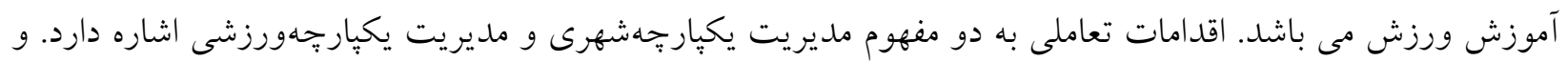
در نهايت اقدامات عمرانى نيز داراى دو مفهوم ايجاد زيرساختهاى كلانشهرى و ايجاد زيرساختهاى ورزشى مىباشد. بنابر اين همانطور كه اودونوان، مك فيلى و كريك در تحقيق سال (•l(Y) خود عنوان كردند: مىتوان از ابزار ورزش به عنوان وسيلهاى تربيتى براى ياددهى رفتارها و كنشهاى مثبت شهروندى استفاده كرد (ع (Y). يكى از بزر كترين مشكلات شهرهاى بزرگ، كمبود فضاهاى ورزشى و عدم توزيع صحيح آن با توجه به جمعيت هر منطقه و هم:جنين كمبود و ناكافى بودن منابع مالى وزارت ورزش براى ايجاد اماكن ورزشى است. با شروع شهرنشينى و افزايش جمعيت شهرنشينان و بالتبع مشكلات به وجودآمده، ضرورت فراهم آوردن امكاناتى براى رفاه حال شهروندان بيش از بيش احساس مى گردد (Yo). 


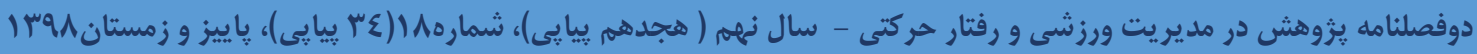

بيامدها

در نتيجه به كار گيرى راهبردهاى ورزش شهروندى، مى توان به ييامدهاى ينجگانه: تامين منافع ملى از دو بعد منافع سياسى و امنيتى، يبامدهاى اقتصادى شامل منافع محيطى، گسترش رفاه عمومى و توسعهى اقتصاد شهرى، از بيامدهاى توسعه ورزشى مفاهيم رشد و توسعه ورزش شهروندى و كسترش سلسله مراتب ورزش اشاره كرد. بيامدهاى بهداشتى -سلامتى ورزش شهروندى داراى دو بعد بهاشت روانى و سلامت جسمى مى باشد و آخرين مقوله از بيامدهاى ورزش شهروندى كه در نتيجه كاربست راهبردهاى آن ايجاد مى گردد ييامدهاى فرهنكى -اجتماعى است با دو بعد فرهنكى (رشد فضايل اخلاقى در ورزش، ساخت جامعه سالم، توسعه خصائص انسانى، افزايش فرهنگ جامعه، جلوكيرى از بروز ناهنجارىها، تقويت مذهبى و...) و اجتماعى (افزايش همبستخى، تقويت بنيان خانواده، كنترل اجتماعى، افزايش سرمايه اجتماعى محلات، تقويت جامعه مدنى و...) اشاره كرد. توسعه ورزش در شهرها علاوه بر افزايش سلامت جسمى و روحى شهروندان بر انسجام اجتماعى، حس تعلق به ساير شهروندان و احساس تعلق به جامعه را افزايش مىدهد و تاثيرات بسيار مثبى را در اقدامات گروهى براى بهبود محيط زيست شهرى فراهم مى آورد. با توجه به يافته هاى حاصل از يزوهش رهبرى و همكاران در سال (90ب1) و يبيامدهاى حاصله از مدل تحقيق حاضر مىتوان نتيجه كيرى نمود كه با افزايش و ايجاد اماكن ورزشى در مناطق مختلف شهر و به كارگيرى يك برنامه ورزشى منظم و مداوم از سوى شهروندان مىتوان ابعاد مختلف كيفيت زندگى شهروندان را افزايش

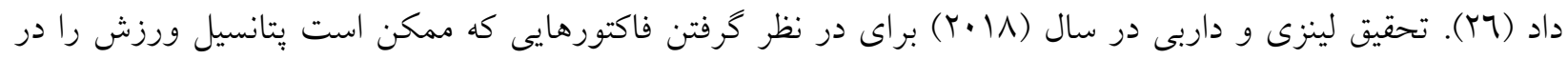
توسعه يايدار فعال كنند، بيشنهاد مى كند سياستخذاران و محققان به سمت مفهوم انسجام سياسى هدايت شوند (YV). با توجه به نتايج يزوهش حاضر، به نظر مى آيد مدل ارايهشده زمينه درى صحيحى از ورزش شهروندى را فراهمآوردهو سياستخاران و مديران شهرى و ورزشى را قادر به آسيب شناسى كاملى از شرايط ورزش در كلانشهر تهران سازد تا با اجراى راهبردهاى مناسب ذكر شده، موجب رشد و توسعه رفاه و سلامتى شهروندان شوند. مدل اين يُزوهش مىتواند با ارائه ديد جامعى از ورزش شهروندى و عوامل موثر بر آن، و شناسايى بيامدهاى آن، ضمن يكيارجهاسازى تلاشهاى سران كشور جهت توسعه منافع ورزش در كلانشهرها، از موازى كارىهاى غيرضرورى جهت هزينهكرد فعاليتهاى اجرايى در خصوص مشاركت شهروندان در ورزش جلو گيرى كرده و ضمن حفظ حقوق شهروندان و فراهمكردن بستر و امكانات مناسب ورزشى براى آنان، هويت محلى تهرانى ها را در عصر جهانىسازى و كاهش احساس تعلق، ارتقا دهد. بيشنهاد مىشود سياستخذاران و برنامهريزان ارشد شهرى، با عنايت به شرايط على مدل حاضر، به عواملى كه موجب تقويت مشاركت در ورزش شهروندان است، توجه ويزهاى داشته باشند. همينطور با شناخت عو امل تضعيف كننده ورزش شهروندى، برنامهريزى لازم را براى كاهش يا به حداقلرساندن اين عوامل صورتدهند، جر اكه اين كار مىتواند منجر به

https://jrsm.khu.ac.ir/ 


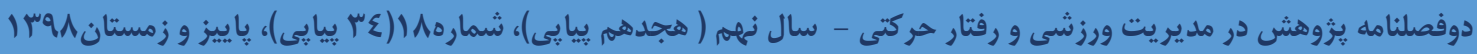

تضمين منافع ملى، يِيامدهاى اجتماعى، فرهنكى و اقتصادى گردد. از طرفى با توجه به مقوله مهم تبليغات و رسانهها، يششنهاد مى شود صداوسيماى جمهورى|سلامىايران خصوصا شبكه تهران، با توجه به بيامدهاى مثبت ورزش شهروندى در جامعه، راهبردهاى تبليغاتى مناسب را به كار برده و ساعات خاصى را به برنامه ورزش شهروندى اختصاص دهند. همجنين لازم است مديران شهرى با برقرارى تعامل مثبت با شوراى شهر، دولت و مجلس، بودجه مناسب به توسعه زيرساختهاى شهرى بلاخص زيرساختهاى مرتبط با ورزش اختصاص دهند. با عنايت به نتايج بدست آمده از تحقيق، با توجه به اينكه فراوانى كدهاى ورزش قهرمانى و هويت ايرانى -اسلامى (به ترتيب از مفاهيم ورزش و شهروندى)، بيش از ساير مفاهيم بود، بنابر اين به متوليان ورزش شهروندى بيشنهاد مى گردد تا در تحقيقات و برنامهريزىهاى آتى خود، با تمركز و اولويت بخشى بر اين مفاهيم، در جهت رشد و توسعه ورزش شهروندى كلانشهر تهران كامبردارند. در تحقيق حاضر با توجّه به اينكه مورد مطالعه در كلانشهر تهران به صورت تخصّصى مورد بزوهش قرار كرفت، مىتوان به برخى از محدوديتهايى كه جهت كردآورى و تحليل دادهها، محقّق با آن روبرو بودند اشاره كرد: ا- با توجّه به جديد بودن مفهوم ورزش شهروندى و كمبود منابع علمى در اين حوزه، اكثر اعضاى هيأت علمى و دانشخاهى، آشنايى مختصرى با آن داشته و به دليل عدم تسلط بر بحث، متأسفانه در مصاحبهها مشاركت نمى -

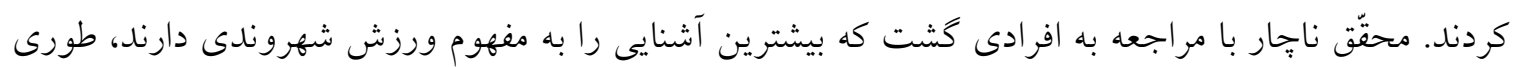
كه به صورت نظرى، عملى و اجرايى درگير فعّاليّتهاى ورزش شهروندى در كلانشهر تهران هستند كه بيشترين افراد مربوط به مديران، كارمندان و مربيان سازمان ورزش شهردارى تهران و تربيت بدنى مناطق r كانه شهردارى

$$
\text { تهران بود. }
$$

Y- متأسفانه يكى از مباحث مطرح شده مهم توسط خبر گان حاضر در مصاحبه هاى يزوهش حاضر، عدم وجود مديريت يكيارجهى شهرى و تداخل وظايف و موازى كارىها و عدم هماهنكى هاى كاه و بيخاه بين اركانهاى خدمترسان سطح شهر بود كه علاوه بر اينكه مستلزم صرف بودجه و منابع و سرمايهى انسانى است، باعث هدر

$$
\text { رفت بودجها و سرمايه ملّى مى گردد. }
$$

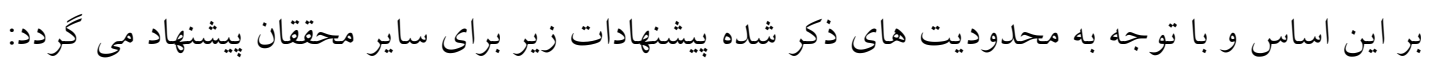
1- حركت در جهت بررسى ورزش شهروندى، مستلزم درك يك مدل مفهومى از كليه عو امل مؤثّر و مطرح در مسئله ورزش شهروندى است. يكى از مزاياى يزوهش هاى بنيادى بسط دانش نظرى و توسعه مفاهيم است. بنابر اين نتايج يزوهش حاضر مى تواند دانش يزوهشخران را در مورد اين مفهوم افزايش دهد تا اين مفهوم هرجه بيشتر در منابع علمى رشد و توسعه يابد. بنابراين به بزّوهشخران بيشنهاد مى گردد تحقيقات بيشترى

$$
\text { بر روى ورزش شهروندى صورت دهند. }
$$




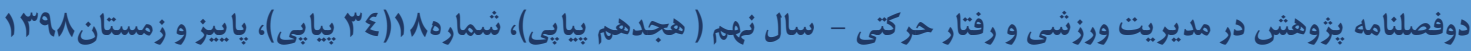

بيشنهاد مىشود محقّقين حوزه مديريت شهرى، بر اساس مدل حاضر يك سيستم مديريت يكيارجّهى شهرى حاكم شود تا در تمامى مؤلّفهاى برنامهريزى شهرى، فعّاليّتهاى عمرانى - زير ساختى، برنامههاى فرهنكى و نظارت و ارزيابى، همسويى و هم افزايى ايجاد كشته و باصرف كمترين بودجه و زمان، بيشترين بازدهى در بيشبرد وظايف مديريت شهرى حاكم شود. البتّه اين امر بسيار مهم است و بايد توسط اركانهاى ذىصلاح مشكلات ساختارى و ادارى شهرى بررسى شده و سبس اقدام قانونى و قاطع انجام داد.

منابع

1. Balish, S.M. 2017. Democracy predicts sport and recreation membership: Insights from 52 countries. Journal of epidemiology and global health, 7(1), pp.21-28.

r.رحمانى نيا، فرهاد. وادى خيل، حسن. (•وب1). ورزش شهروندى و سلامتى. مجموعه مقالات دومين همايش ملى توسعه ورزش شهروندى. ص

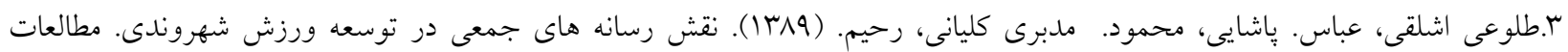

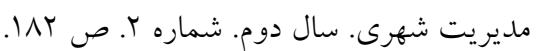

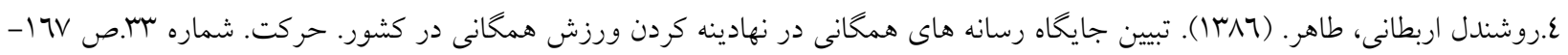

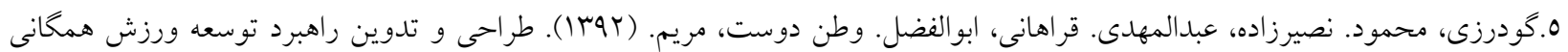
استان كرمان. مديريت ورزشى. دوره 0. 7. سليمى آوانسر، على. (•وبا ). نخرشى نوين در ورزش شهروندى. تهران. مجموعه مقالات دومين همايش ملى توسعه ورزش شهروندى. ص TYM-YTO

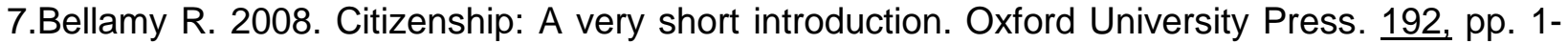
139.

1.محسنى، رحيم على. (9/1). ابعاد و تحليل حقوق شهروندى؛ راه كارهايى براى تربيت و آموزش حقوق شهروندى. مطالعات سياسى.سال .

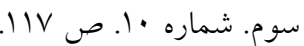

9.عيوضى، محمد رحيم. باب كوره، سيد حسام الدين. (1+1). تحول مفهوم شهروندى و ظهور شهروند جهانى. سياست.سال جهل و دوم.

$$
\text { شماره r. }
$$

10. Imanzadeh, M. and Gündoğdu, C. 2014. The effect of developed citizen sport in increased prestige of municipality. International Journal of Sport Studies, 4(7), pp.789-792.

11. Forsyth, J. 2014. Aboriginal sport in the city: Implications for participation, health, and policy in Canada. aboriginal policy studies, 3(1-2), pp. 213-222.

12. Howat, G. and Assaker, G., 2016. Outcome quality in participant sport and recreation service quality models: Empirical results from public aquatic centres in Australia. Sport Management Review, 19(5), pp.520-535.

سا. سوارى، سعيد. مهدى يور، عبدالرحمن. رنجبر، روح الله. عهبا. توصيف وضعيت ورزش همگانى استان خوزستان و تدوين راهبردهاى

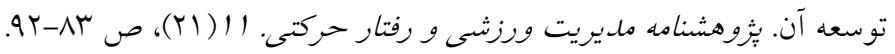

https://jrsm.khu.ac.ir/ 


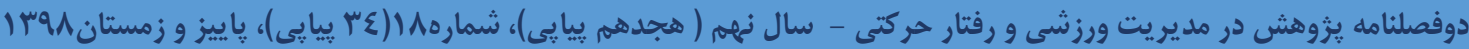

ع ا. كشكر، سارا. عqسا. تعيين شاخصها و نحوه سنجش اثربخشى برنامه هاى تفريحات ورزشى (ورزش همخانى) شهروندان. ثُوهشنامه

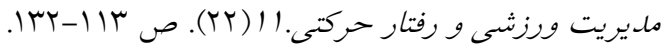

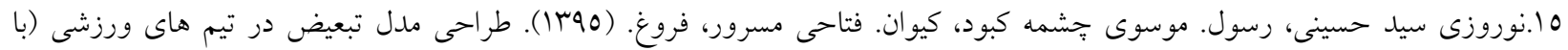

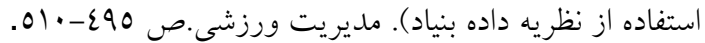


ص ص

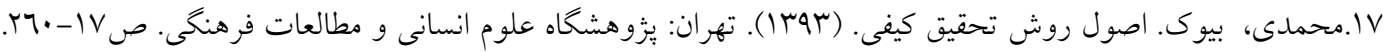

18. Aman, M.S., Mohamed, M. and Omar-Fauzee, M.S. 2009. Sport for all and elite sport: Underlining values and aims for government involvement via leisure policy. European journal of social sciences, 9(4), pp.659-668.

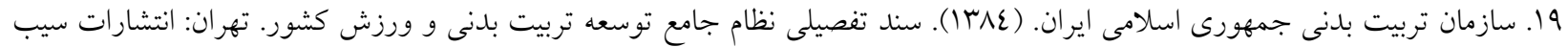

20. Delanty, G. 1997. Models of citizenship: defining European identity and citizenship. Citizenship studies, 1(3), pp.285-303.

21. Imanzadeh, M. and Gündoğdu, C. 2014. The municipality's role in the development of sport for all from citizen's views. International Journal of Sport Studies, 4(7), pp.806-809.

22. Hoekstra, F., Roberts, L., van Lindert, C., Martin Ginis, K.A., van der Woude, L.H. and McColl, M.A. 2018. National approaches to promote sports and physical activity in adults with disabilities: examples from the Netherlands and Canada. Disability and rehabilitation, pp.1-10.

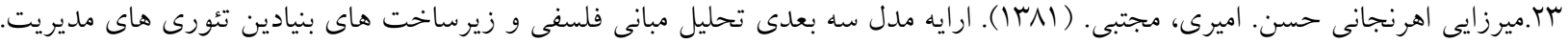

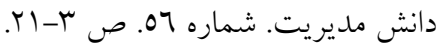

24. O'Donovan, T.M., MacPhail, A. and Kirk, D. 2010. Active citizenship through sport education. Education 3-13, 38(2), pp.203-215.

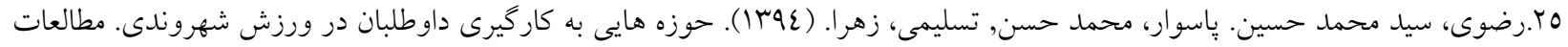

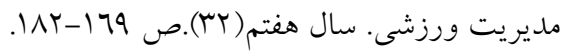

דr.رهبرى، سعيد, مستحفظيان، مينا. نادريان جهرمى، مسعود. (9001). مقايسه كيفيت زندكى شهروندان بهره ور و غيربهره ور از اماكن ورزشى

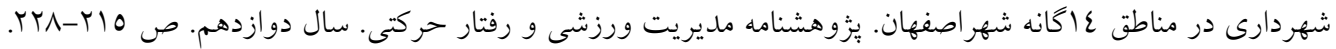

27. Lindsey I, Darby P. 2018. Sport and the Sustainable Development Goals: Where is the policy Pp1-32..coherence? .International Review for the Sociology of Sport, p. 1012690217752651 